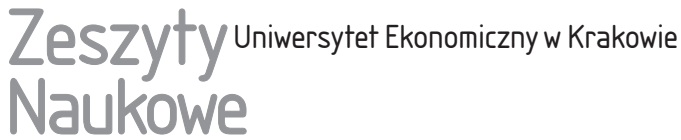

\section{Koncepcja informatycznych narzędzi komunikacji wewnętrznej w sądach powszechnych*}

\section{Streszczenie}

W artykule zaprezentowano koncepcję dobrej praktyki z zakresu IT, której ideą jest zastosowanie informatycznych narzędzi komunikacyjnych w działalności polskich jednostek wymiaru sprawiedliwości. Koncepcja dobrej praktyki powstała podczas wdrożenia pilotażu dobrego zarządzania jednostkami wymiaru sprawiedliwości w ramach projektu „PWP Edukacja w dziedzinie zarządzania czasem i kosztami postępowań sądowych case management” programu operacyjnego „Kapitał ludzki”. Celem dobrej praktyki „Informatyczne narzędzia komunikacji wewnętrznej” jest poprawa jakości i szybkości komunikacji pomiędzy pracownikami sądu, na wszystkich jego szczeblach, dzięki wprowadzeniu intranetowej platformy komunikacji wewnętrznej (IPKW). IPKW składa się z takich komponentów, jak: wewnętrzny portal komunikacyjny, wewnętrzna poczta elektroniczna, książka adresowa, kalendarze, zadania oraz komunikator. Platforma umożliwiała zastąpienie obiegu informacji realizowanego za pomocą dokumentów papierowych ich formą elektroniczną przesyłaną jako treść listów elektronicznych, ich załączników lub komunikatów bezpośrednich. Drugim obszarem zastosowania platformy było tworzenie wspólnych elektronicznych archiwów danych (pism, zarządzeń, procedur itp). Wprowadzenie elektronicznej platformy komunikacyjnej, oprócz podniesienia sprawności obiegu informacji, powinno doprowadzić do znacznych oszczędności kosztów całego procesu. $\mathrm{W}$ artykule przedstawiono założenia dobrej praktyki, jej koncepcję technologiczną oraz etapy i wyniki jej wdrożenia w ramach projektu.

Jan Trąbka, Uniwersytet Ekonomiczny w Krakowie, Wydział Zarządzania, Katedra Informatyki, ul. Rakowicka 27,31-510 Kraków, e-mail: trabkaj@uek.krakow.pl

* Artykuł powstał w wyniku prac nad projektem pt. „PWP Edukacja w dziedzinie zarządzania czasem i kosztami postępowań sądowych - case management”, nr projektu POKL.05.03.00-00-012/11. 
Słowa kluczowe: intranet portal, CMS, zintegrowane platformy komunikacyjne, e-mail systems, Zimbra, Joomla.

Klasyfikacja JEL: M15, K00.

\section{Wprowadzenie}

W artykule przedstawiono koncepcję zastosowania informatycznych narzędzi komunikacji wewnętrznej w pracy polskich jednostek wymiaru sprawiedliwości. Podczas realizacji projektu „PWP Edukacja w dziedzinie zarządzania czasem i kosztami postępowań sądowych - case management" programu operacyjnego „Kapitał ludzki” została opracowana własna koncepcja informatycznych narzędzi komunikacji wewnętrznej w sądach powszechnych. Autor był członkiem zespołu pracowników Uniwersytetu Ekonomicznego w Krakowie, który opracowywał dobre praktyki (koncepcji narzędzi informatycznych lub organizacyjnych) dla jednostek wymiaru sprawiedliwości w obszarze informatycznym. Opis otoczenia i warunków realizacji projektu oraz wszystkie etapy tworzenia praktyk z zakresu IT przedstawione zostały w artykule (Grabowski, Madej i Trąbka 2018), który można potraktować jako artykuł wprowadzający do prezentowanego zagadnienia.

Celem niniejszego artykułu jest przedstawienie zaproponowanej w ramach projektu koncepcji wykorzystania nowoczesnych, informatycznych narzędzi komunikacji wewnętrznej do wsparcia orzeczniczej i administracyjnej działalności jednostek sądowych wszystkich szczebli. Zaproponowane narzędzia, nazwane w dalszej części artykułu internetowymi platformami komunikacji wewnętrznej (IPKW), są rozwijane i eksploatowane w przedsiębiorstwach od lat 90. XX w., a ich zakres funkcjonalny nadal się powiększa. IPKW należy rozumieć jako zestaw narzędzi komunikacji i pracy grupowej dostępnych dla wszystkich pracowników sądu za pośrednictwem wewnętrznej sieci komputerowej tzw. intranetu (Levine i Baroudi 1995, Bremmer, Iasi i Servati 1997). W początkowych stadiach były to niezależnie funkcjonujące aplikacje i usługi: poczta elektroniczna, kalendarze, wewnętrzne serwisy WWW czy narzędzia pracy grupowej (Bolek 2012). Obecnie niezależne narzędzia i technologie łączy się pod wspólnym określeniem systemów zarządzania treścią w przedsiębiorstwie (Enterprise Content Management) (Trąbka 2015).

Intranetowe platformy komunikacji wewnętrznej są powszechnie wykorzystywane w organizacjach biznesowych. Można postawić pytanie badawcze, w jakim stopniu z narzędzi informatycznych, w węższym kontekście narzędzi komunikacyjnych, korzysta administracja sądownicza w Polsce i na świecie. Analiza literatury zagranicznej pozwala wymienić nielicznie publikacje. Poniższe przykłady odnoszą się do fragmentarycznych rozwiązań dziedzinowych dostosowanych zwykle do specyfiki prawodawstwa danego kraju, np. klasyfikowanie 
petycji sądowych w sprawie e-sądu (Bueno i in. 2003), wprowadzanie cyfrowego powiadomienia o dokumentach sądowych (Luzuriaga i Cechich 2011). Dotychczas nie prowadzono badań komunikacyjnych aspektów wewnętrznych struktur jednostek sądowych. W literaturze polskiej M. Rojewski (2012) opisuje wdrożenie systemów Krajowego Rejestru Sądowego oraz ksiąg wieczystych. Autor wskazuje, że projekt ten jest największym osiągnięciem polskiego wymiaru sprawiedliwości w XXI w. System Krajowego Rejestru Sądowego oraz ksiąg wieczystych jest rodzajem centralnej ewidencji, a nie systemem wspierającym wewnętrzną komunikację w jednostkach sądowych. Autorzy pracy (Informatyzacja... 2016) wskazują przemiany prawa wywołane stosowaniem narzędzi informatycznych na przykładzie prawa cywilnego procesowego. Podkreślają możliwość radykalnej poprawy szybkości i jakości działalności sadów dzięki zastosowaniu technologii informatycznych (IT). Jednocześnie wskazują przeszkody techniczne, organizacyjne i mentalne, które mogą opóźnić lub uniemożliwić wdrożenie innowacji informatycznych. Podsumowując, analiza literatury nie daje nawet wstępnych odpowiedzi na postawione pytanie badawcze. Opracowanie ma na celu wypełnienie tej luki.

Istotnie ważnym czynnikiem budowania i wdrażania koncepcji informatycznych narzędzi stały się przeszkody organizacyjne i mentalne. Sądy okazały się specyficznymi organizacjami podlegającymi bardzo wielu regulacjom prawnym i organizacyjnym. Ta specyfika powoduje, że trudniej jest stosować w nich metody wdrażania nowych narzędzi informatycznych, które są skuteczne w organizacjach biznesowych. Jednostki wymiaru sprawiedliwości posiadają bardzo rozbudowane struktury organizacyjne, w których obowiązują silne relacje hierarchiczne. Obecnie przepisy prawa polskiego, pod wpływem prawodawstwa UE, w coraz większym stopniu uwzględniają wykorzystanie elektronicznych form obiegu informacji i decyzji. Jednak większość personelu jednostek sądowych ,wychowała się” tylko na papierowych formach obiegu spraw orzeczniczych i administracyjnych. Większość ankietowanych w trakcie projektu jednostek sądowych nie używała do obsługi obiegu informacji i dokumentów we własnych jednostkach takich narzędzi jak platformy komunikacyjne. W niniejszym opracowaniu podjęto próbę pokazania zalet i korzyści przejścia z papierowych na elektroniczne formy informacji, aby dać mocne argumenty za zmianą dotychczasowych narzędzi obiegu informacji osobom zarządzającym jednostkami sądowymi.

W pierwszej kolejności omówiono założenia organizacyjne oraz cele i oszacowane korzyści wynikające z wdrożenia internetowych platform komunikacyjnych. W dalszej kolejności zaproponowano rozwiązania techniczne oraz etapy prac, jakie powinna podjąć jednostka sądowa, aby wdrożyć IPKW. Artykuł zakończono wskazaniem, na podstawie ankiet przeprowadzonych z pracownikami sądów pilotażowych, zalet, wad oraz wniosków z wdrożenia omawianego narzędzia. 


\section{Podstawowe założenia internetowej platformy komunikacji wewnętrznej}

Przedmiotem omawianej koncepcji jest wdrożenie w sądach biorących udział w projekcie zestawu narzędzi informatycznych wykorzystywanych do usprawnienia komunikacji wewnętrznej pomiędzy pracownikami jednostki sądowej. IPKW koncentruje się na trzech najistotniejszych funkcjach:

- informacyjnej - udostępniającej zasoby informacji ogólnoorganizacyjnej, najczęściej za pośrednictwem strony internetowej, tzw. intranetowego portalu wewnętrznego,

- komunikacyjnej - pozwalającej na obieg informacji i dokumentów w postaci elektronicznej za pomocą wewnętrznej poczty elektronicznej,

- pracy grupowej - pozwalającej na wspólną pracę grup pracowniczych na współdzielonych dokumentach, kalendarzach oraz na określanie, delegowanie i kontrolowanie zadań.

Konwersja tradycyjnych papierowych form komunikacji do formy elektronicznej jest wyraźnie widoczna w organizacjach różnych specjalności i branż na świecie i w Polsce. Szybkość i jakość informacji przy jednoczesnych radykalnych oszczędnościach kosztów jej przetwarzania jest czynnikiem wskazującym na nieuchronną tendencję do wdrażania narzędzi takich jak intranetowe platformy komunikacji wewnętrznej. Potwierdzają to wyniki badania TNS Pentor (Kondycja... 2005, s. 1), a mianowicie: „Intranet, rozumiany jako wewnętrzny serwis WWW, który udostępnia dane i usługi niezbędne pracownikom w codziennych działaniach i służy komunikacji pomiędzy nimi, posiada 59\% największych firm w Polsce". Próba badawcza wynosiła 300 przedsiębiorstw, wylosowanych spośród 2000 firm osiągających najwyższe przychody według dziennika „Rzeczpospolita”. Tendencję tę potwierdzają również aktualne badania (Tatar i Kos-Łabędowicz 2014), które porównują stopień wykorzystania narzędzi internetowych w polskich przedsiębiorstwach na tle krajów UE. Z badań wynika, że przy pewnych czynnościach, takich jak korzystanie z e-administracji czy wymiana danych w formie elektronicznej, nasycenie wykorzystania tych narzędzi znacznie przewyższa średnie wartość osiągnięte dla krajów UE. Biorąc pod uwagę te dane, można uznać, że osiągnięty poziom wykorzystania narzędzi internetowych i intranetowych w przedsiębiorstwach jest bardzo wysoki i dynamicznie się zwiększa. W kontekście jednostek wymiaru sprawiedliwości przeprowadzone badania nie potwierdzają tak optymistycznych wyników. Sąd jest jednostką, która ma inne cele i zadania niż przedsiębiorstwo komercyjne, jednak pod względem informacyjnym, posiadając złożoną strukturę organizacyjną, w wielu przypadkach bardziej złożone procesy, przetwarzając ogromne ilości danych, wymaga również sprawnych narzędzi komunikacyjnych. Dlatego też zarekomendowano wdrożenie intranetowej platformy 
komunikacyjnej w jednostkach sądowych uczestniczących w wymienionym we wstępie projekcie.

Intranetowa platforma komunikacji wewnętrznej jest zestawem narzędzi, które można wdrażać etapami i takie podejście będzie sugerowane. Analizując dane diagnostyczne nadesłane przez sądy biorące udział we wdrożeniu pilotażowym, można zauważyć, że zasadniczo wszystkie jednostki rozpoczęły już wykorzystywanie elektronicznych narzędzi komunikacyjnych, co wskazuje na zrozumienie znaczenia korzyści tej dobrej praktyki. $Z$ analizy nadesłanych przez sądy danych oraz odbytych wizytacji również wynika, że żadna jednostkach nie wykorzystuje jednocześnie trzech najistotniejszych funkcji IPKW. Zaproponowany w ramach dobrej praktyki „Informatyczne narzędzia komunikacji wewnętrznej” układ narzędzi zapewni uzupełnienie już istniejących w sądach rozwiązań o dodatkowe funkcje oraz zapewni ich integrację.

\section{Cele i korzyści wynikające $z$ wdrożenia koncepcji intranetowych platform komunikacji wewnętrznej}

\subsection{Cele i funkcje intranetowych platform komunikacji wewnętrznej}

Celem koncepcji IPKW jest poprawa sprawności i szybkości komunikacji pomiędzy pracownikami sądu na wszystkich jego szczeblach. Sąd jest instytucją o rozbudowanej strukturze organizacyjnej. Komunikacja pomiędzy jednostkami organizacyjnymi oraz poszczególnymi pracownikami wymaga sprawnego narzędzia opartego na systemach teleinformatycznych. Komunikacja tradycyjna odznacza się czasochłonnością, jest zagrożona błędami i jednocześnie cechuje się bardzo dużą kosztochłonnością materiałów, różnego rodzaju mediów, a przede wszystkim pracy. Wdrożenie narzędzi teleinformatycznych może znacznie zredukować występowanie błędów i koszty.

Intranetowa platforma komunikacji wewnętrznej obsługiwać będzie różne obszary.

1. Portal wewnętrzny - udostępnia, za pośrednictwem strony WWW, wspólne zasoby informacyjne dla całej jednostki sądowej. Portal może obsługiwać następujące grupy tematyczne:

- biuletyn informacyjny - aktualności z życia sądu z formie krótkich komunikatów z możliwością umieszczania treści multimedialnych. Biuletyn może również automatycznie publikować aktualności z innych serwisów tematycznych np. Ministerstwa Sprawiedliwości czy Krajowej Szkoły Sądownictwa i Prokuratury,

- baza teleadresowa pracowników jednostki,

- akty prawne i regulacje organizacyjne, 
- instrukcje stanowiskowe - podzielony na obszary zestaw instrukcji dotyczących różnych dziedzin pracy, np. programów komputerowych, procedur kadrowo-płacowych, administracyjnych itd.,

- serwisy informacyjne poszczególnych jednostek sądu, np. wydziałów i oddziałów, które prezentują informacje o danej jednostce, jak również informacje i komunikaty kierowane z jednostki do pozostałych pracowników sądu,

- baza wzorów pism i dokumentów administracyjnych (np. wnioski urlopowe, zaliczki, delegacje),

- pytania i porady - prowadzone w formie forum dyskusyjnego moderowanego przez specjalistów z danych dziedzin,

- połączenia z innymi systemami sądowymi - e-wokandą, helpdeskiem itp.

Administratorem technicznym portalu jest Dział IT, jednak najistotniejszą kwestią jest możliwość łatwego umieszczania treści na portalu przez pracowników innych działów (nieinformatycznych). Do tego celu służą systemy Content Management System (CMS), które umożliwiają tworzenie stron informacyjnych, ich rozbudowę i aktualizację bez konieczności posiadania kompetencji informatycznych, np. znajomości języka tworzenia stron internetowych HTML (Varens 2012, Frankowski 2007). Obsługa systemu CMS z poziomu osoby dodającej czy aktualizującej treści skomplikowaniem odpowiada pracy w edytorze tekstu MS Word.

2. Wewnętrzna poczta elektroniczna - w której każdy pracownik posiada imienną skrzynkę pocztową. Ponieważ cały system pocztowy będzie działał w obrębie wewnętrznej sieci jednostki sądowej, odbiorcami i nadawcami wiadomości mogą być tylko pracownicy sądu. W niektórych wizytowanych sądach na poziomie apelacji łączone są wewnętrzne systemy pocztowe, co daje dodatkowe duże oszczędności czasu i kosztów. Aby sprawnie realizować obieg dokumentów i spraw, system informatyczny powinien „znać” strukturę organizacyjną, $\mathrm{tj}$. jednostki organizacyjne i stanowiska pracy (funkcje). Systemy pocztowe pozwalają na takie odwzorowanie poprzez możliwość definicji grup użytkowników, np. Wydział I Karny, oddział administracyjny. Jednocześnie możliwe jest tworzenie tzw. funkcyjnych skrzynek pocztowych, takich np. jak: dyrektor, kierownicy wydziału, informatyk. Wewnętrzna poczta elektroniczna może zastąpić tradycyjną formę komunikacji w zakresie przekazywania poleceń, informowania, przekazywania oraz odbioru dokumentów (również trafiających do jednostki sądowej w formie papierowej, po ich skanowaniu). Główne funkcje wewnętrznej poczty elektronicznej to:

- baza adresowa - odzwierciedlająca strukturę organizacyjną sądu, adresy skrzynek personalnych, funkcyjnych i grupowych; możliwość tworzenia tzw. list dyskusyjnych, które odzwierciedlającą grupy pracowników, 
- obieg korespondencji wchodzącej i wychodzącej - korespondencja papierowa przed wejściem do obiegu jest skanowana w sekretariacie i załączana do korespondencji elektronicznej,

- mechanizmy kontroli dostarczenia/odbioru korespondencji,

- archiwizacja korespondencji.

3. Komunikatory. Bardzo istotnym elementem IPKW są komunikatory służące do bezpośredniej tekstowej komunikacji pomiędzy użytkownikami. Komunikatory zastępują kontakt telefoniczny w sytuacji, gdy jest on niemożliwy do wykonania lub niewygodny (np. przeszkadza w prowadzeniu rozprawy lub zakłóca pracę pozostałych pracowników).

4. Praca grupowa na wspólnych zasobach. Za pośrednictwem IPKW można tworzyć i recenzować dokumenty w tworzonych dynamicznie grupach. Grupy można tworzyć zgodnie ze zdefiniowaną strukturą organizacyjną skrzynek pocztowych. Główne funkcje platformy komunikacji wewnętrznej w zakresie pracy grupowej to:

- udostępniane repozytoria dokumentów elektronicznych (również multimedialnych),

- wspólna praca nad dokumentami; tworzenie współdzielonych katalogów (np. para sędzia - asystent), na których jednocześnie pracuje grupa pracowników; mechanizm zapewnia spójność dokumentu oraz jego wersjonowanie,

- kontrola praw dostępu do poszczególnych katalogów oraz dokumentów (administracja, redakcja, wygląd).

5. Zarządzanie czasem. IPKW umożliwia tworzenie kalendarzy dla pracowników, grup pracowniczych oraz zasobów. Kalendarze prezentują w dowolnym układzie czasowym obciążenie zasobów, służą do organizacji pracy jednej osoby lub grupy pracowników. Kalendarze zapewniają przypominanie o zbliżających się terminach poszczególnych zdarzeń i mogą być udostępniane publicznie bądź wybranym pracownikom i grupom. Przełożeni mogą na jednym widoku śledzić obciążenie kilku zasobów i dynamicznie alokować zadania. W ramach zarządzania czasem IPKW oferuje wygodny mechanizm organizacji spotkań i innych zdarzeń organizacyjnych.

6. Zarządzanie zadaniami. IPKW wspomaga prowadzenie i dokumentowanie różnorodnych przedsięwzięć przeprowadzanych w ramach organizacji sądowych. Przedsięwzięcia mogą mieć charakter jednostkowych projektów (np. przygotowanie konferencji, remont obiektu) lub też mieć charakter cykliczny, w którym są dynamicznie zlecane zadania dla grupy pracowniczej (np. kierownik działu IT zleca podległym informatykom zadania i kontroluje je). Zadanie ma ramy czasowe, stopień zaawansowania, możliwe jest również dodawanie dokumentów w formie elektronicznej jako załączników. Zadania mogą być udostępniane wska- 
zanym pracownikom lub grupom z przydziałem określonych uprawnień do ich modyfikacji.

\subsection{Korzyści z wdrożenia intranetowych platform komunikacji wewnętrznej}

Korzyści z wdrożenia IPKW mogą być rozpatrywane w trzech aspektach: organizacji pracy, pracownika oraz finansowym.

Aspekt organizacji pracy:

- przyspieszenie i uporządkowanie obiegu informacji,

- poprawa jakości i bezbłędności obiegu informacji,

- łatwe śledzenie drogi dokumentu od momentu wpłynięcia do sądu do zakończenia sprawy,

- zwiększenie skuteczności i gwarancji obiegu informacji,

- lepsza kontrola działań pracowników,

- stworzenie trwałych archiwów informacji i dokumentów.

Aspekt pracownika:

- łatwość dostępu do ważnych informacji (nieograniczona czasowo i terytorialnie),

- mniejsza czasochłonność czynności komunikacyjnych oraz dostępu (wyszukiwania) do potrzebnych informacji,

- stworzenie ogólnodostępnych źródeł wiedzy o organizacji i jej procedurach,

- poprawienie ergonomii pracy,

- wsparcie zarządzania osobistym czasem pracy,

- możliwość uczestnictwa w wewnętrznych forach społecznościowych, co korzystnie wpłynie na kontakty międzyludzkie i utożsamianie się pracownika z organizacją.

Aspekt finansowy:

- redukcja kosztów materiałów biurowych, sprzętu i pracy, wykorzystywanych przy realizacji obiegu, przetwarzania i archiwizowania informacji (wobec obiegu za pomocą dokumentów papierowych),

- redukcja kosztów związanych z archiwizacją dokumentów,

- redukcja strat wynikłych z nieaktualnego obiegu informacji.

Szybkość i jakość obiegu informacji jest parametrem trudnym do przeliczenia na pieniądze. W celu przedstawienia oszczędności finansowych związanych z redukcją kosztów materiałów biurowych i pracy przeprowadzono symulację pokazującą koszt obiegu sprawy w tradycyjnym, papierowym obiegu, kolportowanej z działu administracji do grupy pracowników zarządzających jednostkami organizacyjnymi sądu. Przyjęto założenia, że grupa pracowników liczy 40 osób, koszt wydruku jednej kartki papieru 0,1 zł (wartość przyjęta przez Ministerstwo Administracji i Cyfryzacji do szacowania kosztów procesów obiegu dokumentów), 
czas pracy poświeconej na kopiowanie 1 strony $5 \mathrm{~s}$, a czas fizycznego dostarczenia korespondencji do odbiorcy 2 min. Rozróżniono sprawy wymagające kopii 2 kartek papieru (mała), 10 (średnia) oraz 30 (duża). Koszt wydruku oraz nakład pracy na wydruk i dostarczenie dla poszczególnych spraw wyniósł:

- dla sprawy małej 8 zł oraz 1,44 roboczogodziny,

- dla sprawy średniej 40 zł oraz 1,89 roboczogodziny,

- dla sprawy dużej 120 zł oraz 3 roboczogodziny.

Dla wskazania rocznych wartości przyjęto założenie, że w jednostce sądowej proceduje się 1000 spraw małych, 200 średnich i 50 dużych. Roczne koszty wydruku wyniosły 22000 zł, a nakład pracy wyniósł 1972 roboczogodziny, co daje (przy założeniu 22-dniowego miesiąca roboczego) 11,2 osobomiesiąca, czyli prawie 1 pełny etat rocznie. Przyjęte parametry liczby spraw, w ocenie przedstawicieli wizytowanych sądów, są charakterystyczne dla mniejszych jednostek. W symulacji uwzględniono tylko jeden charakter sprawy i zawężono grono odbiorców tylko do najwyższego szczebla zarządzania organizacji sądowej, dlatego w praktyce skala oszczędności jest znacznie większa. Przykład miał na celu pokazanie pracochłonności, którą elektroniczny obieg informacji zasadniczo eliminuje.

Wyliczenia nie uwzględniają kosztów wyszukiwania i archiwizowania dokumentów papierowych, które w jednostkach sądowych również odgrywają ogromną rolę. Szacunki na ten temat można znaleźć w raporcie firmy Progmate - producenta oprogramowania do zarządzania obiegiem dokumentów (Potencjalne oszczędności... 2012), w którym przytoczone są badania firmy PriceWaterhouseCoopers. Wyliczyła ona, że szukanie, wyjmowanie, przemieszczanie pojedynczego dokumentu zajmuje pracownikowi administracyjnemu średnio od 9 do $12 \mathrm{~min}$, ponadto ok. $40 \%$ znalezionych i przejrzanych dokumentów okazuje się nieprzydatne do wykonania zleconego pracownikowi zadania.

\section{Charakterystyka koncepcji intranetowych platform komunikacji wewnętrznej}

\subsection{Założenia i zakres działania intranetowych platform komunikacji wewnętrznej}

Dobra praktyka wskazuje na możliwości i korzyści wykorzystania elektronicznej platformy komunikacji wewnętrznej w trzech głównych funkcjach: informacyjnej, komunikacyjnej oraz pracy grupowej. Do wymienionych funkcji zostaną przyporządkowane narzędzia informatyczne, które posiadają odpowiednie funkcjonalności oraz zostały już wdrożone pilotażowo w niektórych jednostkach sądów lub są stosowane i polecane przez inne jednostki administracji. Z racji 
założeń praktyki, rekomendowane są systemy open source, których wykorzystanie nie wiąże się z ponoszeniem kosztów licencyjnych. Uwzględniając uwagi ze spotkań w sądach pilotażowych oraz wyniki analizy poziomów zaawansowania poszczególnych sądów, zarekomendowano rozpatrywanie wdrożenia praktyki jako wyboru, z zaproponowanego zestawu narzędzi, elementów uzupełniających już funkcjonujące w sądzie oprzyrządowanie w zakresie jednej z głównych funkcji. Funkcje można traktować jako równie ważne, np. sąd posiadający już wewnętrzną pocztę elektroniczną może wdrożyć portal wewnętrzny, pomimo że funkcja ta jest wymieniana w pierwszej kolejności. Zaproponowane tutaj narzędzia mają charakter zintegrowany, tzn. opisywana platforma komunikacji wewnętrznej ma wszystkie elementy funkcji komunikacyjnej (poczta elektroniczna, komunikator) oraz pracy grupowej (kalendarze, zadania, aktówkę). Gdy jednostka sądowa ma już któryś z elementów obsłużony w innym narzędziu i nie będzie skłonna do jego wymiany, może uzupełnić brakujące funkcje niezależnym narzędziem wybranym na etapie wdrożenia.

Poniżej wskazano rekomendowane do realizacji praktyki narzędzia informatyczne i krótko opisano główne etapy ich wdrożenia.

\subsection{Opis narzędzi informatycznych wykorzystywanych w ramach koncepcji intranetowych platform komunikacji wewnętrznej}

\section{Portal wewnętrzny}

W celu realizacji wszystkich wymienionych wcześniej funkcji portalu wewnętrznego, z dodatkowym jednak warunkiem - możliwości dodawania i aktualizacji treści przez administratorów merytorycznych (nieinformatyków), potrzebne jest narzędzie informatyczne zaliczane do klasy systemów Content Management System (Frankowski 2007). CMS jest programem komputerowym, który wspomaga użytkownika przy tworzeniu stron internetowych, jednocześnie obsługując ich udostępnianie dla użytkowników poprzez serwer WWW. Stronę WWW należy rozumieć jako pewien szablon, który administrator merytoryczny wypełnia treścią: tekstami, zdjęciami, plikami czy filmami. Systemy CMS składają się z panelu administracyjnego do zarządzania układem treści i jej dodawania oraz aplikacji, która zapewnia wyświetlanie strony dla jej użytkowników. Obecnie większość zastosowań serwisów WWW wewnątrzorganizacyjnych dotyczy publikacji i przekazywania aktualnych treści tekstowych bez wyszukanej strony graficznej, dlatego wykorzystanie systemów CMS staje się standardem. Na rynku funkcjonuje już bardzo wiele narzędzi tego typu, są one dostarczane zarówno jako produkty komercyjne, jak i open source (z możliwością wykorzystywania bez ponoszenia opłat licencyjnych). Z racji założeń projektu oraz bardzo szerokiej funkcjonalności i wielu referencji, narzędzia open source będą rekomendowane w opisywanej prak- 
tyce. Do najbardziej popularnych open source systemów CMS należą Wordpress (wordpress.com) i Joomla (joomla.pl).

Najpopularniejszym darmowym oprogramowaniem typu CMS jest Joomla (Burge 2012). Umożliwia ona publikację różnorodnych treści: aktualności, blogów, zdjęć, dokumentów, wydarzeń i wielu innych treści multimedialnych. Wspomniane oprogramowanie jest rozwijane od $2000 \mathrm{r}$. przez organizację typu non profit zrzeszającą 200000 członków. Jest wykorzystywana przez korporacje różnej wielkości, jak również instytucje rządowe i edukacyjne na świecie i w Polsce, np.: Harvard University (Educational) - http://gsas.harvard.edu, Ministerstwo Edukacji Narodowej - http://men.gov.pl, Komendę Wojewódzką Policji w Gorzowie Wielkopolskim - http://www.lubuska.policja.gov.pl.

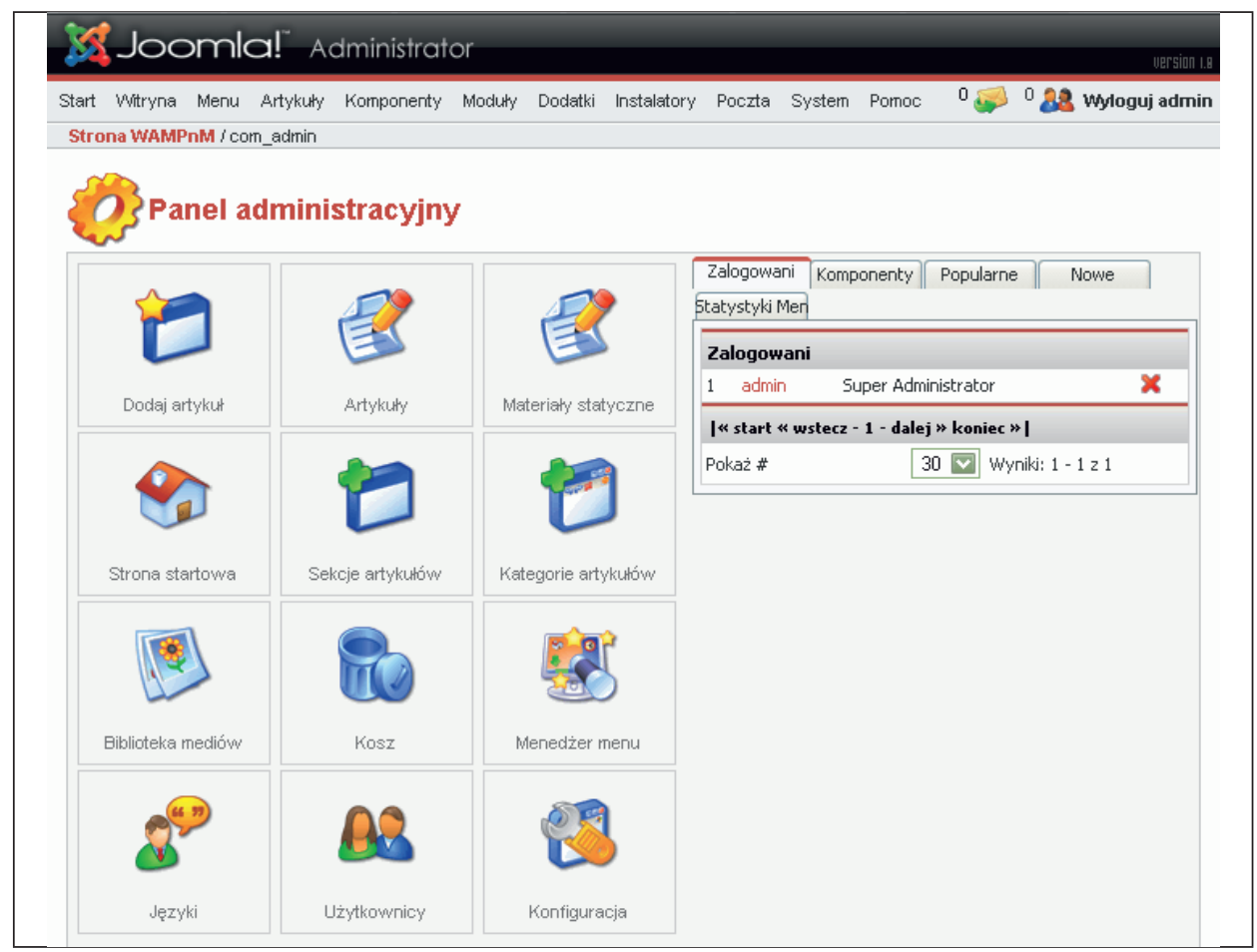

Rys. 1. Panel administracyjny systemu CMS Joomla

Źródło: opracowanie własne na podstawie materiałów z portalu joomla.pl.

Dwa z sądów pilotażowych również wykorzystały to narzędzie do budowy portalu wewnętrznego. Początkowa instalacja dostarcza wszystkich podstawowych funkcji koniecznych do zarządzania zawartością strony. Moduły wymienione jako możliwe do wykorzystania w sądowym portalu wewnętrznym również są 
obsługiwane w standardowej instalacji narzędzia. W systemie zawarte są także pewne elementy o specyficznej funkcjonalności, np. rejestracja użytkownika, interaktywne sondy, katalogi kontaktów i wiele innych. Wbudowany interfejs administracyjny jest bardzo intuicyjny, co daje możliwość aktualizacji treści, np. dodawania artykułów czy dokumentów przez osoby niebędące informatykami. Przykład interfejsu administracyjnego systemu Joomla zaprezentowano na rys. 1.

\section{Platforma komunikacji wewnętrznej}

Platforma komunikacji wewnętrznej wymaga przede wszystkim serwera poczty elektronicznej jako podstawy. Dodatkowymi istotnymi elementami są moduły obsługujące pracę grupową na dokumentach, zarządzanie czasem i zadaniami. W ramach omawianej dobrej praktyki zarekomendowano oprogramowanie firmy VMWare o nazwie Zimbra, które jest z powodzeniem wykorzystywane przez Sąd Okręgowy w Gliwicach oraz kilkanaście sądów w całej apelacji katowickiej. Ogromną zaletą tego narzędzia jest jego licencja open source. Pod względem funkcjonalnym narzędzie porównywalne jest $\mathrm{z}$ najpopularniejszym komercyjnym narzędziem tego typu serwerem Exchange firmy Microsoft. Rozwojem tego narzędzia zajmuje się amerykańska firma VMware (firma notowana na NYSE, zatrudniająca ponad 7 tys. pracowników). Fakt ten daje gwarancje stabilnego rozwoju narzędzia mimo jego charakteru open source. Środowisko Zimbra jest zgodne z nowoczesną infrastrukturą techniczną i systemową, w tym systemem Linux i Mac OS X po stronie serwera, systemem Windows, Linux i Mac na stacji roboczej oraz przeglądarkami internetowymi Firefox, Safari i Internet Explorer.

Do charakterystyki funkcjonalnej i technicznej środowiska Zimbra wykorzystano materiały z portalu producenta (zimbra.com) oraz polskich organizacji wdrażających to rozwiązanie (intalio.pl, ergomedia.pl). Pod względem technologicznym Zimbra to zestaw komponentów: Zimbra Server, Zimbra Web Client i Zimbra Desktop. Poniżej przedstawiono krótką charakterystykę wybranych modułów funkcjonalnych systemu Zimbra. W kolejności opisano pocztę, komunikator oraz kalendarze.

Poczta Zimbra oferuje takie funkcjonalności, jak:

- łatwe tworzenie, edytowanie, usuwanie i odpowiadanie na wiadomości,

- tworzenie i udostępnianie folderów pocztowych,

- przenoszenie wiadomości do folderów za pomocą funkcji „przeciągnij i upuść",

- przeglądanie i edytowanie załączonych dokumentów bez konieczności zapisywania ich na dysku komputera,

- automatycznie grupowanie wiadomości dotyczące jednej konwersacji na podstawie tematu,

- możliwość ustanowienia reguł. 
Komunikator wewnętrzny. Podstawową zaletą komunikatora Zimbra jest jego uruchomienie $\mathrm{w}$ jednostce sądowej bez potrzeby instalowania oprogramowania zewnętrznego. Komunikator oferuje takie funkcjonalności, jak:

- identyfikacje użytkowników z listy adresowej,

- udostępnianie statusów użytkownika,

- możliwość zachowania treści komunikatów w folderze.

Kalendarz Zimbry pozwala zaplanować i śledzić wszystkie spotkania i wydarzenia oraz gospodarować zasobami. Użytkownicy mogą przełączać się między wieloma widokami (dzień, tydzień, tydzień roboczy, miesiąc), korzystać z funkcji „przeciągnij i upuść” w celu przenoszenia elementów z jednego kalendarza do innego, wydłużać czas trwania spotkania przez rozciągnięcie spotkania w kalendarzu i udostępniać kalendarze innym użytkownikom.

Lista referencyjna systemu Zimbra zawiera wiele polskich jednostek administracji, edukacji oraz firm, takich jak np. (w nawisie podano liczbę obsługiwanych kont pocztowych): Ministerstwo Środowiska w Warszawie (600), Urząd Miasta Łódź (2200), Urząd Miasta Lublin (1500), Lubuski Urząd Wojewódzki (500), Mazowiecki Urząd Wojewódzki (1600) oraz Uniwersytet Ekonomiczny w Krakowie.

\subsection{Etapy wdrożenia intranetowych platform komunikacji wewnętrznej}

Etapy wdrożenia intranetowej platformy komunikacji wewnętrznej zakładają wykorzystanie opisanych powyżej narzędzi informatycznych. W przypadku wyboru przez sąd innych narzędzi etapy wdrożeniowe należało każdorazowo dostosować do ich specyfiki.

Regulacje prawne. Ważnym elementem wdrożenia elektronicznej komunikacji wewnętrznej jest jej usankcjonowanie odpowiednim zarządzeniem prezesa sądu. Pracownik musi mieć obowiązek regularnego (np. minimum dwukrotnego w trakcie dnia pracy) sprawdzania zawartości swojej skrzynki pocztowej.

Faza wdrożenia portalu wewnętrznego:

- instalacja i konfiguracja komponentów systemu Joomla (serwera WWW, bazy danych, aplikacji głównej),

- nadanie praw dla administratorów merytorycznych oraz konfiguracja zabezpieczeń i archiwizacji portalu,

- szkolenie administratorów merytorycznych odpowiedzialnych za redakcję poszczególnych modułów portalu.

Faza wdrożenia wewnętrznej poczty elektronicznej:

- instalacja i konfiguracja systemu Zimbra na serwerze,

- założenie kont dla użytkowników (import z systemu kontrolera domeny),

- definicja kont grupowych lub list dystrybucyjnych, 
- konfiguracja archiwizacji danych,

- szkolenie dla użytkowników końcowych; dobrą praktyką w tym zakresie może być opublikowanie na portalu wewnętrznym instrukcji obsługi lub filmów instruktażowych.

Faza wdrożenia mechanizmów pracy grupowej (kalendarze, zadania, aktówka). Opisywany wariant zakłada wykorzystanie integralnej platformy komunikacji wewnętrznej Zimba, która została już zainstalowana w poprzedniej fazie, dlatego w tej fazie jest zawężony tylko do szkolenia użytkowników końcowych.

\section{Wnioski z wdrożenia koncepcji intranetowych platform komunikacji wewnętrznej}

Dobra praktyka „Informatyczne narzędzia komunikacji wewnętrznej”, w której podstawą była omawiana w niniejszej pracy koncepcja, została wdrożona w 42 sądach, $\mathrm{w}$ tym w $25 \mathrm{w}$ ramach pilotażu podstawowego oraz w 17 sądach $\mathrm{w}$ ramach pilotażu uzupełniającego (Badanie ewaluacyjne... 2015). Wśród sądów, które wybrały dobrą praktykę, był m.in. Sąd Apelacyjny w Białymstoku, Sąd Okręgowy Warszawa-Praga w Warszawie, Sąd Okręgowy w Rzeszowie, Sąd Rejonowy dla Krakowa-Krowodrzy w Krakowie, Sąd Rejonowy dla Krakowa-Śródmieścia w Krakowie. Harmonogram wdrażania oraz poziom zaawansowania prac w poszczególnych sądach pilotażowych zamieszczone zostały w opracowaniu (Raport całościowy... 2014).

Podczas współpracy autora z firmą wdrażającą zalecenia i narzędzia dobrej praktyki powstały raporty, na podstawie których można było zestawić zalety i ograniczenia oraz wnioski podsumowujące. Prezentowane dane zostały zebrane w trakcie przeprowadzonych wywiadów z pracownikami sądów (metodą ITI i CAWI).

Do głównych zalet opisywanej praktyki przedstawiciele sądów zaliczyli:

- stworzenie dodatkowego kanału komunikacji,

- odciążenie pracowników od ciągłego odbierania telefonów,

- poprawę organizacji obsługi IT,

- szybszy i lepszy przepływ informacji w sądzie,

- szybszą realizację zadań - dobre narzędzie komunikacji wewnętrznej po właściwym przeszkoleniu pracowników,

- lepszą dostępność do dokumentów dla pracowników, możliwość trwałego załatwiania skomplikowanych spraw za pomocą wiadomości,

- rozwój wiedzy o możliwościach stosowania narzędzi informatycznej komunikacji.

Do ograniczeń oraz trudności podczas wdrażania dobrej praktyki respondenci zaliczyli: 
- czasochłonność,

- szeroki zakres praktyki - wymaga nie tylko wprowadzenia, ale stałej kontroli na różnych płaszczyznach, a do tego potrzebni są ludzie i środki,

- wykorzystanie darmowego oprogramowania nieintegrującego się z domeną AD utrudnia administrację, co prowadzi do dezaktualizacji informacji,

- skomplikowany przebieg niektórych wdrożonych procedur,

- wielkość sądu oraz różnorodny stopień obsługi komputera sprawia, że kontakt telefoniczny jest szybszy i chętniej wybierany niż droga elektroniczna,

- opór pracowników przed korzystaniem z tych narzędzi.

Respondowani przedstawiciele sądów przedstawili, związaną z kosztami wdrożenia oraz późniejszą eksploatacją zaproponowanych narzędzi, konkluzję, że wdrożenie dobrej praktyki wymaga przeznaczenia stosownych środków, co jednak przyczyni się w przyszłości do redukcji kosztów w zakresie:

- materiałów biurowych, sprzętu i pracy, wykorzystywanych przy realizacji obiegu, przetwarzania i archiwizowania informacji,

- archiwizacji dokumentów,

- strat wynikłych z nieaktualnego obiegu informacji.

Ostateczna konkluzja pracowników sądu podsumowująca cały proces wdrożeniowy jako wniosek końcowy artykułu (Badanie ewaluacyjne... 2015, s. 177) jest następująca: „Na sprawność funkcjonowania sądów ogromny wpływ ma szybka i skuteczna komunikacja pomiędzy pracownikami sądu, którzy często przebywają w oddalonych od siebie miejscach. Komunikacja nie zawsze możliwa jest przez telefon ze względu na brak synchronizacji osób, których komunikowanie się ma dotyczyć. Dlatego też rozwiązania polegające na wdrożeniu komunikacji za pomocą narzędzi informatycznych mają swoje ogromne zalety i przynoszą wymierne efekty:

- informację można przesłać w każdym momencie, a odbiorca przeczyta ją w możliwym dla siebie terminie,

- dokumenty mogą być przesłane niezwłocznie,

- lepsza organizacja pracy w organizacji rozproszonej,

- łatwość dostępu do różnych informacji,

- łatwość archiwizowania poszczególnych dokumentów".

Powracając do zadanego pytania badawczego, należy stwierdzić, że jednostki sądowe w znacznie mniejszym stopniu wykorzystują rozwiązania informatyczne, tj. IPKW, w porównaniu z organizacjami biznesowymi. Realizacja omawianego projektu potwierdziła spostrzeżenia zawarte w literaturze przedmiotu, że jednostki sądowe zmagają się z problemami technicznymi, organizacyjnymi i mentalnymi, które spowalniają wdrożenie innowacji informatycznych. Omawiany w pracy projekt jest, zdaniem autora, udaną próbą przełamywania barier we wdrażaniu innowacji informatycznych w polskich jednostkach sądowniczych. 


\section{Literatura}

Badanie ewaluacyjne pilotażu wdrażania dobrego zarzqdzania jednostkami wymiaru sprawiedliwości $w$ ramach projektu „PWP Edukacja $w$ dziedzinie zarzqdzania czasem i kosztami postępowań sq̨dowych - case management". Raport końcowy (2015), ASM - Centrum Badań i Analiz Rynku, Kutno.

Bolek J. (2012), Efektywne wykorzystanie klasycznych i nowoczesnych narzedzi komunikacji wewnętrznej przez przedsiębiorstwo (w:) Zarzq̨dzanie kapitałem intelektualnym w organizacji inteligentnej, red. W. Harasim, Wyższa Szkoła Promocji, Warszawa.

Bremmer L.M., Iasi A.F., Servati A. (1997), Intranety Biblia, Mikom, Warszawa.

Bueno T.C.D., Bortolon A., Hoeschl H.C., Mattos E.S., Santos C.S., Theiss I. (2003), Using $R B C$ to Classify Judicial Petitions on e-Court, Proceedings of the 9th International Conference on Artificial Intelligence and Law, ICAIL '03, June 24-28, Edinburgh, Scotland, UK.

Burge S. (2012), Joomla! Oficjalny podręcznik. Ćwiczenia, Helion, Gliwice.

Frankowski P. (2007), CMS. Jak szybko i łatwo stworzyć stronę WWW i zarzqdzać niq, Helion, Gliwice.

Grabowski M., Madej J., Trąbka J. (2018), Koncepcja metodyki projektowania i wdrażania dobrych praktyk informatycznych dla sqdów powszechnych, „Zeszyty Naukowe Uniwersytetu Ekonomicznego w Krakowie”, nr 4(976), https://doi.org/10.15678/ ZNUEK.2018.0976.0413.

Informatyzacja postępowania cywilnego. Teoria i praktyka (2016), red. K. Flaga-Gieruszyńska, J. Gołaczyński, D. Szostek, Seria Monografie Prawnicze, C.H. Beck, Warszawa.

Kondycja polskiego intranetu (2005), http://pentor-arch.tnsglobal.pl/38445.xml?doc_ $\mathrm{id}=11278$ (data dostępu: październik 2016).

Levine J., Baroudi C. (1995), Sekrety Internetu, Readme, Warszawa.

Luzuriaga, J.M., Cechich A. (2011), Electronic Notification of Court Documents: A Case Study, Proceedings of the 5th International Conference on Theory and Practice of Electronic Governance, ICEGOV '11, September 26-28, Tallin, Estonia.

Potencjalne oszczędności wynikajace $z$ wdrożenia elektronicznego systemu obiegu dokumentów (2012), progmate.pl/pl/news/savings (data dostępu: październik 2016).

Raport całościowy z wdrożenia za okres od 1 grudnia 2013 r. do 24 października 2014 r. (2014), oprac. WYG International, WYG Consulting, WYG PSDB, Uniwersytet Ekonomiczny w Krakowie, Instytut Allerhanda na zlecenie Krajowej Szkoły Sądownictwa i Prokuratury, http://www.efs2007-2013.gov.pl/Dokumenty (data dostępu: grudzień 2016).

Rojewski M. (2012), Rola informatyzacji w rozwoju sprawnego sqdownictwa i administracji na przykładzie Krajowego Rejestru Sqqdowego i ksiag wieczystych, „Biuletyn Stowarzyszenia Absolwentów i Przyjaciół Wydziału Prawa Katolickiego Uniwersytetu Lubelskiego", nr 8.

Tatar S., Kos-Łabędowicz J. (2014), Internet w działalności polskich przedsiębiorstw, „Studia Ekonomiczne”, vol. 184.

Trąbka J. (2015) Znaczenie systemów klasy Enterprise Content Management (ECM) dla przedsiębiorstw oraz ich perspektywy technologiczne i rynkowe (w:) Nierówności społeczne a wzrost gospodarczy. Społeczeństwo, przedsiębiorstwa i regiony $w$ dobie 
gospodarki elektronicznej, red. M. Sarama, C. Hales, Wydawnictwo Uniwersytetu Rzeszowskiego, Rzeszów.

Varens K. (2012), Projektowanie systemów CMS przy użyciu PHP i jQuery, Helion, Gliwice.

\section{IT Tools for Internal Communication in Common Courts}

(Abstract)

The article presents the use of IT communication tools as a good practice in the activities of the Polish judicial system. The concept of good practice came into being during the implementation of the pilot project of good management of the subordinate units of the Polish Ministry of Justice as a part of the projects "Education in the time and cost management of judicial proceedings - case management", with the financial resources granted from the European Social Fund within the framework of Human Capital. The aim of the good practice "IT tools for internal communication" is to improve the quality and speed of internal communication across all organisational levels and units by introducing an intranet platform. The platform replaces traditional (paper) communication with an e-mail channel that makes it possible to attach documents (i.e. letters, decrees, policy descriptions, procedures), send direct messages (i.e. instant messaging system) and archive. Implementing the internal platform increases communication efficiency and cost savings. The article presents the assumptions of the good practice, the technology involved in it and the stages of the implementation within the project.

Keywords: intranet portal, CMS, integrated communication platform, e-mail systems, Zimbra, Joomla. 